\title{
Local Engineering Colleges and Universities College English ESP Curriculum Research Orientation and Construction Based on the Requirement Analysis
}

\author{
Kun Yang, Junyan Cai, Xinning Zhang \\ School of Foreign Languages, Hebei University of Technology, Tianjin, 300230, China
}

Key words: Demand analysis, Local Engineering colleges and universities, University English ESP courses, Positioning, Construct

\begin{abstract}
At present, economic globalization and education internationalization trend obviously, so the non-English major students also need to listen to English lectures, use English to read professional literature, at the same time also need to use English to write papers, even in their professional work involves the application of English. Therefore, on the basis of demand analysis, construction of the college English ESP curriculum system has important practical significance, especially in local engineering colleges and universities.
\end{abstract}

\section{Introduction}

At this stage, the national business activities have become more frequent, to some extent improve the needs of English talents, and in the inter-disciplinary talent, English talents play a key role. Therefore, business English talents needs to implement vocational, applied and compound and the all-round development of export-oriented. Therefore, at the local college English teaching in colleges of engineering gradually produced the needs analysis theory, and creating new teaching mode, which provides the cultivation of interdisciplinary talents with better security. So, on the basis of demand analysis, the local college English ESP teaching in colleges of engineering to locate and research plays an important role and value.

\section{The introduction to the theory of demand analysis}

In the process of research of scholars both at home and abroad, the demand Analysis theory to understand for teachers in curriculum design and teaching process through the Analysis of the student' s Needs and investigation, and then clear the specific way of learning content and learning a theory, which is Needs Analysis [1]. At this stage, the requirements analysis theory has three analysis methods, namely the status quo, learners as the center and the target. Among them, the status quo of scenario analysis is in front of the ESP teaching, for learners learning attitude and basic knowledge level and the actual growth environment and so on carries on the comprehensive analysis. And analysis method of learners as the center is to target requirements as specific according to the learners themselves. Target scenario analysis method is the content and the way which carries on the analysis related to language situation, and studies the characteristics of the language and skills, to better achieve learner needs and the combination of language learning. In accordance with the relevant academic point of view, you can see that the ESP teaching in the teaching material content or the actual teaching process, all need to students as the center, take the target scene analysis method, the market environment of comprehensive consideration, and determine the needs of business English talents. Then the present situation of application analysis method, to the students' own language barriers, basic ability compared with the actual work needs, and a comprehensive understanding of, as a curriculum and building materials on the basis of the specific contributions to improve the quality of ESP teaching. 


\section{The ESP model of teaching}

ESP, namely and disciplines related or career in the society such as business, travel and news related to English. The main target and content of the teaching mode with student' s practical application demand as the core set of [2]. Ordinary English compared with speaking, listening, speaking, reading and writing English ESP teaching mode broke through the translation and the form of the basic law of English, pay more attention to the practical application of professional knowledge. Through analysis and study of social linguist, gives the characteristics of ESP courses, is the professional requirements of the content of the English curriculum and social activities, and classroom teaching of language application in professional and career scenario, at the same time the needs of students should be as the most basic principle.

\section{The necessity of college English ESP courses in local place}

ESP teaching mode in the late $1970 \mathrm{~s}$ was introduced into our country, and has attracted much attention in English teaching. Since the mid - ninety - s, ESP teaching mode gradually become the main and applied English talents cultivation methods. And, on the basis of demand analysis, the college English teaching reform and development to carry on the thorough research and analysis. ESP teaching mode's own goal is clear, and has strong pertinence, practicability is strong. The teaching model will be the teaching effect and benefit as the first principle, therefore, it should be based on demand analysis to ESP teaching, and in the choice of teaching content and method, also need to determine according to student's learning needs.

\section{Meeting the needs of foreign language talents}

Through the actual demand, the survey found most people thought in college not only need to culture of foreign language listening, speaking, reading and writing ability, at the same time also need to actively cultivate students professional foreign language ability to work, the main reason is that the demand of the enterprise, students in the actual work can skillfully use English. In addition, in the recruitment of international IT talented person, because more than half of the candidate's professional English reading and writing ability is not in conformity with the enterprise needs and missed out the student's own English level and professional required English has a larger gap. So, in the course of English teaching reform in colleges and universities must be with the requirements of the enterprise and society, especially the local school in colleges of engineering, more should pay attention to the importance of English teaching [3].

\section{It is the bridge of college basic English and professional English teaching}

In the right place of science in colleges of engineering professional students, found that after an investigation into professional teaching in English to the very not adapt, the main reason is the lack of professional vocabulary and reading literature ability is bad, so the students hope to be able to open a bridging course, thus enable it to adapt to professional English teaching of the course as soon as possible. English, however, the ESP teaching can completely realize the needs of students, like business English, science and technology and so on. At the same time, these courses are the same as students' English curriculum and the basis and premise of bilingual courses, and for students to learn professional English courses for language and content of comprehensive security.

\section{Building English ESP curriculum model in college local place}

College English ESP curriculum pattern mainly includes three parts, respectively, to strengthen the language, academic skills and special purpose, 12 credits, students need to use 2 to 4 students to complete learning [4].

\section{Language intensive course}

Belong to take this course nature, 0 to 2 credits, mainly includes two kinds of content, namely a subject-based English skills and English. Among them, a subject based English compared with the original comprehensive English, it' $\mathrm{s}$ the theme of the text the strong correlation with students' professional background and for medical students, the theme of the text is the basic principle of 
medical, public health, the medical profession achievement and so on. And for art students of physical education class, the text theme professional also needs the same period has a certain relevance. Generally speaking, a subject-based English teaching content is used to as a carrier and the backing, thus achieve the purpose of to improve their English ability. English skill is the original individual skills courses in speaking, writing and listening teaching. Intensive American language's main advantage is all the course content does not belong to compulsory course, and some even no credit courses, to a certain extent for students to fill foundation provides favorable conditions and the individuality demand. However, credits set needs to be determined according to the actual situation of school and professional.

\section{Academic skills courses}

This course belongs to the compulsory nature, 8 credits, also consists of two courses, namely academic written communication and oral communication. Academic written communication among them, the course mainly includes the content of the thesis writing and literature reading, etc., while academic oral communication mainly includes the academic discussion speech and hearing lectures, and so on. Can be opened in the first semester academic lectures and reading content, and can be opened in the second semester academic presentations and writing, etc. Among them, each course has two credits, students can come forward to two courses at the same time, and as a 4 credit hours of courses, and then on the two courses can also be at the same time, the same as a 4 credit course. In addition, academic lectures and reading can be divided based on feature, for example, a semester has eight projects, of which six for interdisciplinary content, such as nanotechnology, environmental protection, the physical universe, or genetic engineering, etc., and the rest of the two courses can be combined with specific professional students, and then choose to have professional qualitative literature and lectures. At the same time, in the academic lectures and reading can be inserted into the lecture includes listening and note-taking skills, or read fast that exist in the reading skill of word guessing strategy and context and so on. While academic writing should be in the choice of topic research as a starting point, teaching students how to collect valuable documents, and how to do literature review, summary of papers and references of writing and so on.

\section{The course for special purposes}

This course belongs to take as an elective course, occupy 2 credits. Of course for special purposes should be in accordance with the specific characteristics of different schools in the design, such as legal English, business English, this is all for the professional requirements of the concrete. And all English courses, specialized courses major of business English and legal English stylistic research in depth, and vocabulary, discourse and a variety of characteristics of sentence structure, the core is the language. However, all is the core of the English curriculum content knowledge, is the courses in the specialized teachers. In addition, professional use English and academic English courses, there are many differences between the same academic English courses belong to the interdisciplinary teaching, is common, its core is the teaching of academic skills.

\section{The specific strategies of improving the college English ESP teaching in local place}

According to "college English curriculum requirements", can clear the ultimate goal of English teaching is to improve students' English comprehensive application ability, and make it better able to apply in work and activities. However, although the present college English teaching has made significant achievements, however, in the process of English ESP teaching always exist some shortcomings, like teachers ignore the important role of this teaching mode, and the weak. At the same time, most of the colleges and universities to include English ESP teaching in the teaching of basic knowledge of English, so, the classroom teaching content attach more importance to language skills learning. In view of the problems existing in ESP teaching English, a certain concern must be paid, and to take targeted measures to make it perfect and improve.

\section{The curriculum principles}

On the basis of demand analysis, it needs to be done according to the following principles in the university English ESP teaching Settings: 
The first is the target principle. To achieve the goal of college English compound talents cultivation, requires English professional knowledge, skills, and pay a attention with related courses. Among them, the English professional knowledge and professional skill course is English teaching content of ESP courses, courses including technology, economy, trade, management and tourism knowledge [5]. Therefore, ESP courses in the aspect of setting need consistent with specific syllabus, and will develop English talents as the ultimate teaching goal.

The second is the systemic principle. Relevant scholars think English ESP teaching system mainly includes the professional knowledge and language knowledge of English, also include the content of the management and communication skills and cultural awareness, and is conducive to better improve students' theoretical knowledge and practical knowledge of English skills.

The third is the principle of authenticity. Using the ESP teaching mode is the most important is the authenticity of the entire process; the key is in the application of the basic language skills.

\section{Correct understanding of general English teaching and ESP teaching}

Through the above analysis and research, we can found that has a certain relationship between general English teachings with ESP teaching, but also have many differences. So, in the process of college English teaching, should attach importance to general English teaching in junior stage, however, need to ESP English teaching as auxiliary teaching way. In the senior stage, they need to emphasis on ESP teaching, not only the need of the common English teaching content to consolidate on a regular basis, but also should pay attention to the opening of relevant other courses, and make students master basic knowledge of English on the basis of constantly improve their English skills.

\section{To improve the teaching means and teaching evaluation model}

In recent years, the information age coming, for the teaching of college English provides more and more superior conditions, therefore, at the time of ESP teaching in English classes, teachers can also or the multimedia technology is to make full use of computer technology, thus effectively improve students' listening skills. At the same time, the teacher can also introduce the corresponding simulations, and constantly improve the students' ability of English practical application.

\section{To improve English teachers' comprehensive quality}

Local English teaching in colleges of engineering need English teachers have high comprehensive quality, only in this way can in the process of cultivating English talents exert its advantage and value, and ESP English courses for students learning has certain positive role

\section{Conclusion}

Above all, on the basis of demand analysis, ESP college English course teaching in the future will occupy the important position in English teaching and its effect will be more and more important. ESP of college English teaching must be based on reality, and need to according to the current college English teaching situation, set the course of principle as the foundation, actively improve the specific teaching methods and evaluation model, thus effectively promote the teaching level, ultimately achieve the purpose of the teaching quality and students' comprehensive ability to improve and promote the college English teaching work smoothly in local place.

\section{Acknowledgments}

This paper is Hebei university of technology education teaching reform project in 2015, project number: 201502025; This paper is college humanities and social science research project of Hebei province in 2015, project number: SZ151252.

\section{References}

[1] Meng Jianguo. The core value of higher vocational college English teaching and study of dynamic conversion, based on the requirement analysis and ESP courses to build horizon. Journal of Xinjiang vocational education research,2012(1):33-37. 
[2] Hou Yanxia, Liu Guilan. Engineering colleges and universities college English ESP curriculum research. Journal of Hubei radio and TV university, 2014,34(8):142-143.

[3] Cai Jigang. The college ESP curriculum research of basing on the requirement analysis. Foreign language teaching, 2012(3):47-50.

[4] Wang Jinxia. The higher vocational ESP course design research based on the theory of the demand analysis, insurance of English, for example. Journal of insurance journals of vocational college, 2012,26(6):80-85.

[5] Cao Xia. Applied undergraduate colleges and universities based on the theory of the demand analysis ESP curriculum. Journal of Hunan first normal college,2013,13(2):89-91,103. 